\title{
Design, Construction and Performance of a Solar Cloths Drying System
}

\author{
Serah. O. Yusuf ${ }^{1}$ Dr. Taiye Ajibola ${ }^{2}$ \& Prof. O. Olasode ${ }^{3}$ \\ ${ }^{1} \mathrm{Ph} . \mathrm{D}$. Scholar, Department of Physics, University of Ilorin, Ilorin, Nigeria \\ ${ }^{2}$ Lecturer, Department of Physics, University of Ilorin, Ilorin, Nigeria \\ ${ }^{3}$ Professor, Department of Engineering, University of Ilorin, Ilorin, Nigeria
}

\begin{abstract}
This paper presents the design, construction and performance evaluation of an efficient stand-alone PV-integrated solar clothes drying system for drying applications. The solar clothes drying system was constructed to reduce the reliance on unsustainable electric dryers, which are high electricity-consuming appliances resulting in the emission of large CO2 amounts to the environment. All these developments were geared towards improving the performance and reliability of the alternative sustainable energy systems and help to reduce environmental hazards. After testing different materials for the construction and the evacuated collector tube, the result shows that copper is the best for high performance and efficiency followed by aluminum. But aluminum was used for the casing and a copper tube for the evacuated collector tube.
\end{abstract}

From the performance evaluation test of the hybrid solar clothes drying system, it was observed that The trend of the variation in temperature was a result of the weather condition the solar drying system was able to dry a pair of clothes within 3 hours during the outdoor test and about 3 hours and 45 minutes during the indoor test with a relative humidity of $30 \%$.

Key Words: Solar Clothes Dryer, Overall Heat Gain, Energy, Moisture Content, Drying Specimen.

\section{INTRODUCTION}

Drying is one of the oldest methods of food preservation. For several thousand years, people have been preserving dates, figs, apricots, grapes, herbs, potatoes, corn, milk, meat, and fish by direct sun drying. Until canning was developed at the end of the 18th century, drying was virtually the only method of food preservation [1]. Solar drying is still the most widely used method for both domestic and industrial applications. The dried fruits and vegetables are lightweight, do not take up much space and do not require refrigerated storage. Direct sun drying is associated with numerous shortcomings, as products are affected by ultraviolet radiation, dust, rain showers, morning dews, animal and human interference, to mention but a few. In addition, open sun drying is slow, has no quality control and has a risk of contamination, creating a potential health hazard. The product's quality is seriously degraded, sometimes to the extent that they are inedible [2].

In many rural locations in Africa and most developing countries, grid connected electricity and supplies of other non-renewable sources of energy are unreliable and too expensive for many farmers [3]. Thus in such areas, crop-drying systems that employ motorized fans or electrical heating are inappropriate. The large initial and running costs of fossil fuel powered dryers present such barriers that small-scale farmers rarely adopt them. Thermal drying systems can be classified into two main groups: high temperature and low temperature dryers, that is; temperature elevations between $10^{\circ} \mathrm{C}$ and $35^{\circ} \mathrm{C}$ above ambient.

Energy is required in all aspects of everyday life, including agriculture, lighting, health-care services and telecommunications, domestic and industrial activities [4]. The trend of total reliance on finite fossil fuels for daily energy demands must change for good; therefore a collective effort is urgently needed to save the environment from the effect of climate change caused by global warming and other ecological degradations which have adverse consequences on the environment. The importance of renewable energy systems cannot be over-emphasized [5]. Today, a reasonable amount of research has been conducted on solar thermal applications. For example, the bulk of existing literature on solar drying relates to food drying applications. It has been observed that solar clothes drying suffer neglect, although it is an equally energy-intensive activity, especially in the developed world. To 
encourage alternative energy application, a hybrid standalone solar drying system was designed, constructed, and evaluated, as part of this research due to its environmental significant importance.

\section{THEORETICAL CONSIDERATIONS}

The solar drying system overall useful heat gain $\left(\mathrm{Q}_{\mathrm{all}}\right)$ is the sum of thermal energy trapped by the photovoltaic $(\mathrm{PV})$ panel $\left(\mathrm{Q}_{\mathrm{pv}}\right)$ and the thermal energy from the evacuated tube collectors $\left(\mathrm{Q}_{\mathrm{etc}}\right)$.

Therefore, the overall thermal energy of the solar drying system is defined as

$$
Q_{a l l}=Q_{p v}+Q_{e t c}
$$

Where, $\mathrm{Q}_{\text {all }}$ is the overall heat generated by the solar system, $\mathrm{Q}_{\mathrm{pv}}$ is the thermal energy from the PV panel and $\mathrm{Q}_{\mathrm{etc}}$ is the generated thermal energy from the evacuated tube collectors.

Useful thermal energy = energy input - energy output - losses

$$
Q_{\text {all }}=I A(\tau \alpha)-(A U * \Delta T)-P_{\text {elect }}
$$

where $\mathrm{P}_{\text {elect }}$ is the electrical power from the PV panel which is given as a function of solar radiation level (I) to the PV panel collector area $\left(\mathrm{A}_{\mathrm{p}}\right)$ multiply by the PV panel efficiency $\eta_{p}$.

$$
P_{\text {elect }}=I A_{p} * \eta_{p}
$$

The drying specimen initial, final and instantaneous moisture content is given by:

$$
M_{i}=\frac{W_{i}-W_{f}}{W_{f}}
$$

where $\mathrm{W}_{\mathrm{i}}$ is the initial weight and $\mathrm{W}_{\mathrm{f}}$ is the final weight of the specimen

The final moisture content $\mathrm{M}_{\mathrm{f}}$ is expressed as

$$
M_{f}=\frac{W_{w e t}-W_{f}}{W_{f}}
$$

where, $\mathrm{W}_{\text {wet }}$ is the wet weight of the drying specimen.

The overall coefficient of performance of system is the total energy output divided by input over the radiation level and collector area.

$$
C_{\text {perf }}=\frac{M_{w} * h_{f g}}{Q_{\text {all }}+P_{\text {elect }}} * \frac{Q_{a}+P_{\text {elect }}}{I A_{\text {total }}}=\frac{M_{w} * h_{f g}}{I A_{\text {total }}}
$$

where, $\mathrm{IA}_{\text {total }}$ is the solar radiation level and the total collector area $\left(\mathrm{A}_{\mathrm{p}}+\mathrm{A}_{\mathrm{etc}}\right)$.

\section{METHODOLOGY}

The solar dryer was constructed with locally available materials. The constructed solar dryer was placed in an open space behind the Department of Physics, Faculty of Physical Sciences and University of Ilorin and was used to perform experiments; the relative humidity, the wind speed and the temperature of the solar dryer were recorded. The indoor and the outdoor performance test was carried out using the constructed solar clothes dryer and also the temperatures, relative humidity and the wind speed were read and recorded for the period of the experiments. Figures 1 show the picture of the solar drying system. The solar clothes dryer consists of two main components: the upper compartment which includes the PV panel, storage battery and fan, the lower compartment include the drying chamber, 12 copper evacuated tube collectors and a plane reflector. Paraffin's $\left(\mathrm{C}_{n} \mathrm{H}_{2 n+2}\right)$ was selected as the phase change material (PCM) because research has shown that they are one of the excellent organic compounds used for storing heat in solar thermal systems. It is cheap and commercially available. It has a specific heat capacity of 2.14-2.9 $\mathrm{J} / \mathrm{g} / \mathrm{K}$, heat of fusion of $200-220 \mathrm{~J} / \mathrm{g}$, melting point of about $37^{\circ} \mathrm{C}(310 \mathrm{~K})$ and a boiling point of $>370^{\circ} \mathrm{C}[6]$. 


\section{International Journal of Advances in Scientific Research and Engineering (ijasre), Vol 7 (4), April -2021}

The heat pipes are embedded in the $1.5 \mathrm{~m}$ ETC which is made of copper $(32 \mathrm{x} 16 \mathrm{~mm})$ for the length and diameter. These tubes are vertically arranged parallel to each other. The casing of the solar drying system is made of metallic copper sheets of thickness $0.5 \mathrm{~mm}$, width $0.14 \mathrm{~m}$ and length $0.74 \mathrm{~m}$. The cover is glass of $5 \mathrm{~mm}$ thick and the rack inside the drying chamber is made of iron rod of $0.3 \mathrm{~m}$ thick.

To enhance the insolation falling on the collectors, a plane reflector booster (north facing) made of plane mirror is mounted at the side of the ETC. All the materials needed for the construction of this solar drying system are locally available. The samples for the investigation of the performance of the solar dryer are laboratory coats of different colours (white and blue) and our local fabric (Ankara).

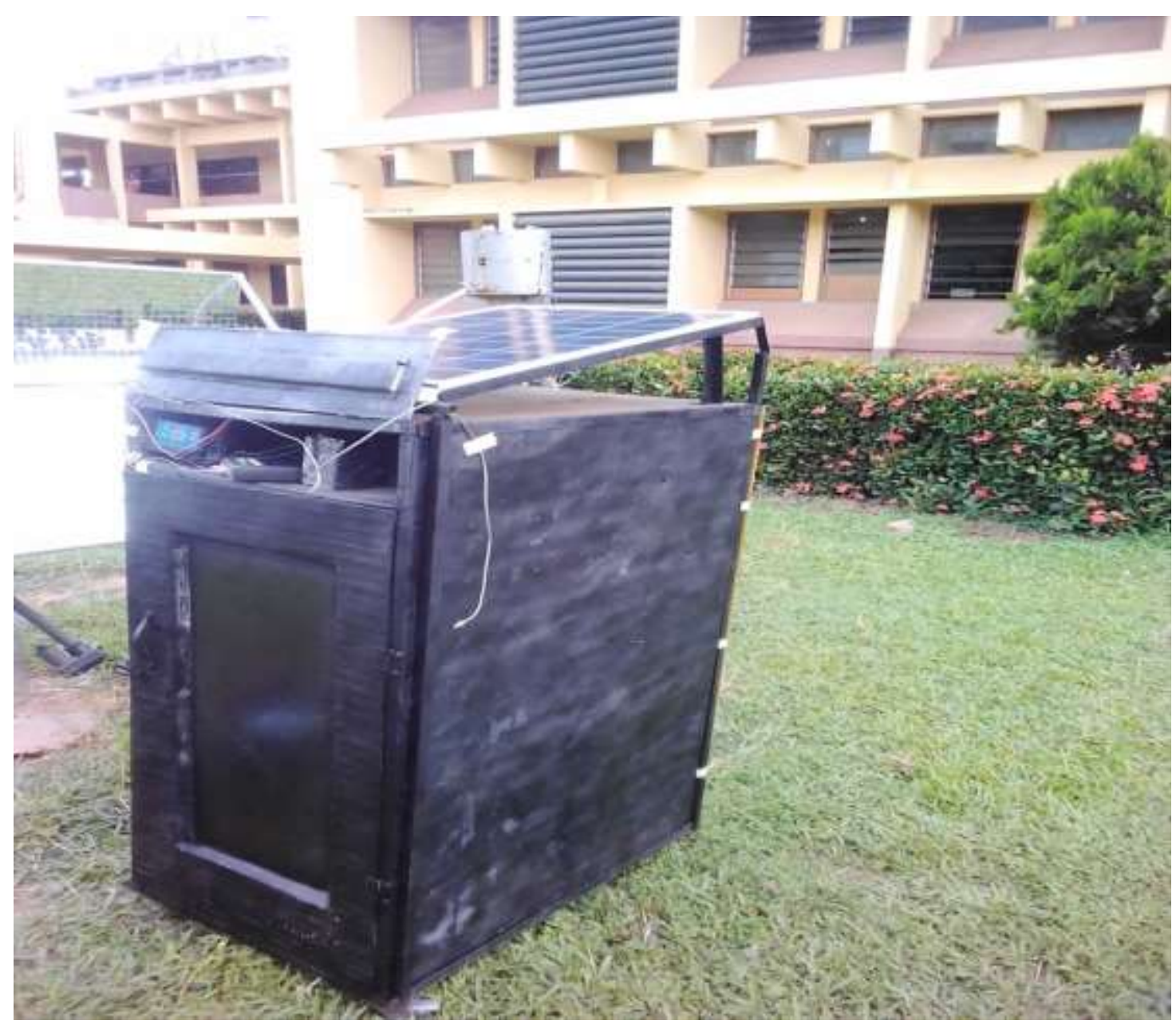

Figure 1: Schematic diagram and picture of the solar cloths drying system

\section{RESULTS AND DISCUSION}

Table 1(a-e) shows the results of the calculated solar thermal collector outlet temperature $\left(\mathrm{T}_{\text {cout }}\right)$ under varying solar radiation levels and mass flow rate from $1.2 \mathrm{~m} / \mathrm{s}$ to $0.8 \mathrm{~m} / \mathrm{s}$ from the results it observed that, the PV outlet temperature $\left(\mathrm{T}_{\text {pout }}\right)$, collector outlet temperature $\left(\mathrm{T}_{\text {cout }}\right)$ and overall heat gain $\left(\mathrm{Q}_{\text {all }}\right)$ all increased with increase in solar radiation levels. The results presented in table 1 below also shows the variations of the $\mathrm{T}_{\text {cout }}$ with solar radiation and air mass flow rate. 
International Journal of Advances in Scientific Research and Engineering (ijasre), Vol 7 (4), April -2021

Table 1a: Computed overall heat gain and thermal collector outlet temperature $\left(T_{a}=27^{\circ} \mathrm{C}\right)$ at fan speed $1.2 \mathrm{~m} / \mathrm{s}$.

\begin{tabular}{|l|l|l|l|l|l|}
\hline $\mathbf{1 1 . 2 m} / \mathbf{s}$ & Solar Rad. $\left(\mathbf{W} / \mathbf{m}^{\mathbf{2}}\right)$ & $\mathbf{M}_{\mathbf{a}}(\mathbf{k g} / \mathbf{s})$ & $\mathbf{T}_{\text {pout }}\left({ }^{\mathbf{0}} \mathbf{C}\right)$ & $\mathbf{T}_{\text {cout }}\left({ }^{\mathbf{o}} \mathbf{C}\right)$ & $\mathbf{Q}_{\text {all }}(\mathbf{W s})$ \\
\hline \multirow{4}{*}{} & 1000 & 0.022 & 36.48 & 98.51 & 1581 \\
\cline { 2 - 6 } & 800 & 0.022 & 35.80 & 85.75 & 1299 \\
\cline { 2 - 6 } & 600 & 0.022 & 34.30 & 72.98 & 102 \\
\cline { 2 - 7 } & 400 & 0.022 & 32.90 & 60.22 & 734 \\
\cline { 2 - 6 } & 200 & 0.022 & 27.30 & 47.44 & 452 \\
\hline
\end{tabular}

Table 1b: Computed overall heat gain and thermal collector outlet temperature $\left(T_{a}=27^{\circ} \mathrm{C}\right)$ at fan speed $1.1 \mathrm{~m} / \mathrm{s}$.

\begin{tabular}{|c|c|c|c|c|c|}
\hline $1.1 \mathrm{~m} / \mathrm{s}$ & Solar Rad. $\left(W / m^{2}\right)$ & $M_{a}(\mathbf{k g} / \mathbf{s})$ & $\mathbf{T}_{\text {pout }}\left({ }^{\circ} \mathbf{C}\right)$ & $\mathbf{T}_{\text {cout }}\left({ }^{\circ} \mathrm{C}\right)$ & $\mathbf{Q}_{\text {all }}(\mathrm{Ws})$ \\
\hline & 1000 & 0.02 & 36.48 & 104.33 & 1709 \\
\hline & 800 & 0.02 & 35.80 & 90.41 & 1402 \\
\hline & 600 & 0.02 & 34.30 & 76.47 & 1094 \\
\hline & 400 & 0.02 & 32.90 & 62.55 & 786 \\
\hline & 200 & 0.02 & 27.30 & 48.63 & 478 \\
\hline
\end{tabular}

Table 1c: Computed overall heat gain and thermal collector outlet temperature $\left(T_{a}=27^{\circ} \mathrm{C}\right)$ at fan speed $1.0 \mathrm{~m} / \mathrm{s}$.

\begin{tabular}{|c|c|c|c|c|c|}
\hline $1.0 \mathrm{~m} / \mathrm{s}$ & Solar Rad. $\left(W / m^{2}\right)$ & $M_{a}(\mathbf{k g} / \mathbf{s})$ & $\mathbf{T}_{\text {pout }}\left({ }^{\circ} \mathbf{C}\right)$ & $\mathbf{T}_{\text {cout }}\left({ }^{\circ} \mathrm{C}\right)$ & $\mathbf{Q}_{\text {all }}(\mathbf{W s})$ \\
\hline & 1000 & 0.018 & 36.48 & 111.2 & 1106 \\
\hline & 800 & 0.018 & 35.80 & 95.91 & 1524 \\
\hline & 600 & 0.018 & 34.30 & 80.59 & 1185 \\
\hline & 400 & 0.018 & 32.90 & 65.29 & 847 \\
\hline & 200 & 0.018 & 27.30 & 49.97 & 508 \\
\hline
\end{tabular}

Table 1d: Computed overall heat gain and thermal collector outlet temperature $\left(T_{a}=27^{\circ} \mathrm{C}\right)$ at fan speed $0.9 \mathrm{~m} / \mathrm{s}$.

\begin{tabular}{|c|c|c|c|c|c|}
\hline $0.9 \mathrm{~m} / \mathrm{s}$ & Solar Rad.(W/m²) & $M_{a}(\mathbf{k g} / \mathbf{s})$ & $\mathbf{T}_{\text {pout }}\left({ }^{\circ} \mathbf{C}\right)$ & $\mathbf{T}_{\text {cout }}\left({ }^{\circ} \mathbf{C}\right)$ & $\mathbf{Q}_{\text {all }}(W s)$ \\
\hline & 1000 & 0.0168 & 36.48 & 116.09 & 1969 \\
\hline & 800 & 0.0168 & 35.80 & $\begin{array}{l}99.81 \\
\end{array}$ & 1609 \\
\hline & 600 & 0.0168 & 34.30 & 83.50 & 1249 \\
\hline & 400 & 0.0168 & 32.90 & 67.24 & 889 \\
\hline & 200 & 0.0168 & 27.30 & 50.95 & 529 \\
\hline
\end{tabular}


International Journal of Advances in Scientific Research and Engineering (ijasre), Vol 7 (4), April -2021

Table 1e: Computed overall heat gain and thermal collector outlet temperature $\left(\mathrm{T}_{\mathrm{a}}=27^{\circ} \mathrm{C}\right)$ at fan speed $0.8 \mathrm{~m} / \mathrm{s}$.

\begin{tabular}{|c|c|c|c|c|c|}
\hline $0.8 \mathrm{~m} / \mathrm{s}$ & Solar Rad.(W/m²) & $M_{a}(k g / s)$ & $\mathbf{T}_{\text {pout }}\left({ }^{0} \mathbf{C}\right)$ & $\mathbf{T}_{\text {cout }}\left({ }^{0} \mathrm{C}\right)$ & $\mathbf{Q}_{\text {all }}(\mathbf{W s})$ \\
\hline & 1000 & 0.015 & 36.48 & 124.65 & 2159 \\
\hline & 800 & 0.015 & 35.80 & 106.65 & 1761 \\
\hline & 600 & 0.015 & 34.30 & 88.65 & 1363 \\
\hline & 400 & 0.015 & 32.90 & 70.66 & 965 \\
\hline & 200 & 0.015 & 27.30 & 52.65 & 567 \\
\hline
\end{tabular}

The parametric analysis of the standalone solar clothes drying system shows that the overall heat gains $\left(Q_{\text {all }}\right)$ increases with increase of solar radiation and mass flow rates respectively. The heat transfer from the solar thermal collector manifold is higher at higher mass flow rate, as the heat removed from the lined up conduction fins is better at higher fan speeds. This shows that the higher the insolation and mass flow rates the better the performance of the solar drying system. The result shows the system's highest performances were achieved at highest insolation and fan speed respectively.

The solar clothes drying tests were conducted without the reflecting boosters. To aid data collection, K-type thermocouples were positioned at the top and at the bottom of the drying chamber and also outside drying chamber respectively. Humidity sensors were used on the control test criterion. According to preliminary experimental data from the developed hybrid solar dryer, clothes achieve an acceptable dryness from $30 \% \mathrm{RH}$ and below. In each case, initial-weight $\left(\mathrm{W}_{\mathrm{i}}\right)$, wet weight $\left(\mathrm{W}_{\text {wet }}\right)$ and dried weight $\left(\mathrm{W}_{\mathrm{d}}\right)$ of the drying specimen were measured

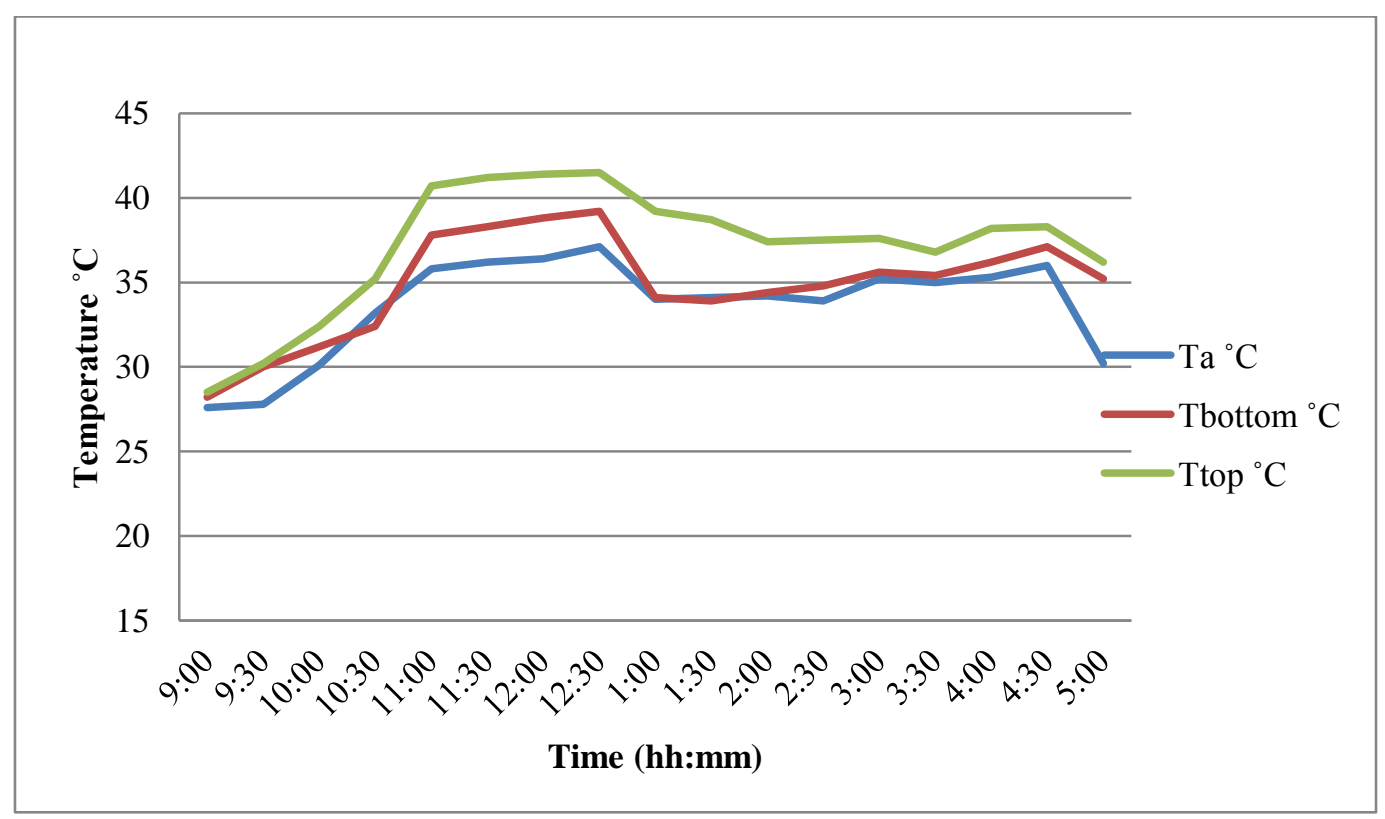

Figure 2: the temperature variations, at the outlet $T_{a}$ of the solar dryer and within the drying chamber ( at the top $\mathbf{T}_{\text {top }}$ and the bottom $\mathbf{T}_{\text {bottom }}$ ).

Figure 2 shows the temperature variation of the outlet temperature $\mathrm{T}_{\mathrm{a}}$, the inlet temperature at the top $\mathrm{T}_{\text {top }}$ and at the bottom $\mathrm{T}_{\text {bottom }}$. The figure also shows a maximum temperature of about $41.5^{\circ} \mathrm{C}$ and a minimum temperature of about $27.6^{\circ} \mathrm{C}$ respectively without reflector booster.

The solar dryer was tested with a reflector. The drying chamber relative humidity decreased from $90 \%$ to $30 \%$ in 3 hours and 30 minutes. This was a reduced drying time of 30 minutes, as a result of increase in the solar radiation by the solar concentrating boosters. 


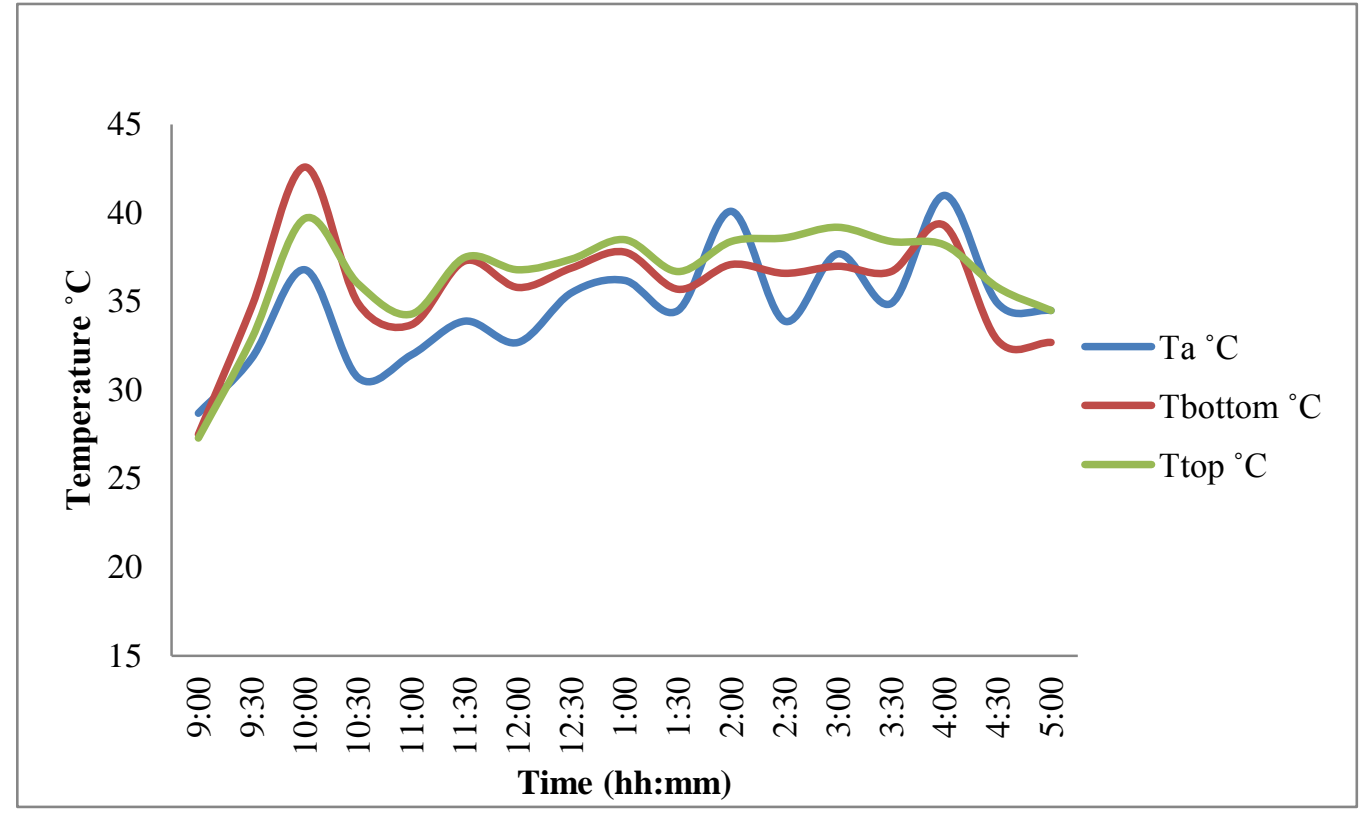

Figure 3: Variations of the outlet temperature $T_{\mathrm{a}}$ and the drying chamber temperature $\left(T_{\text {bottom }}\right.$ and $\left.T_{\text {top }}\right)$ with a reflector booster.

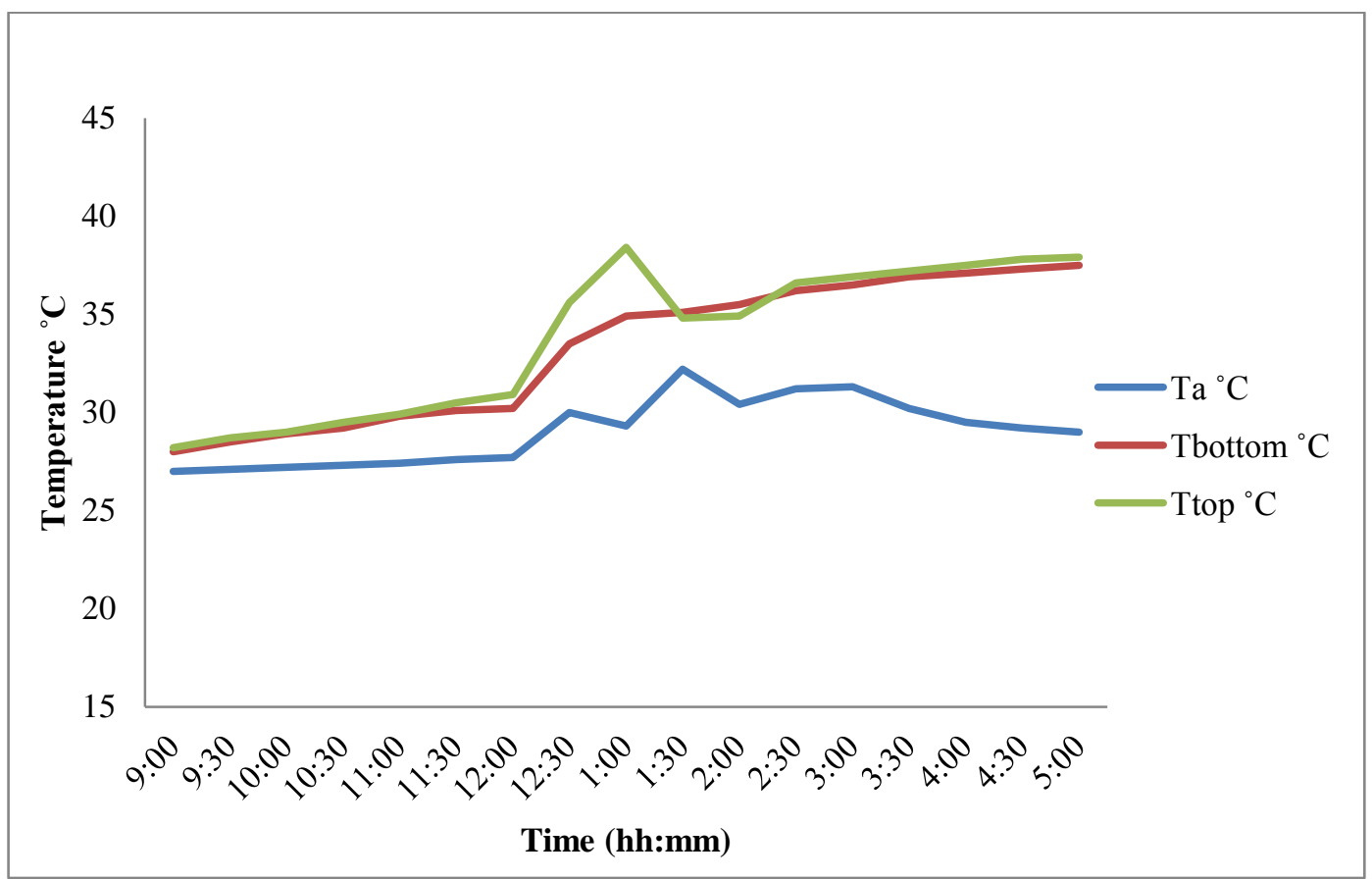

Figure 4: variation in the outlet temperature $T_{a}$ and the drying chamber temperature ( $T_{\text {bottom }}$ and $T_{\text {top }}$ ) with reflector booster.

Figure 3 and 4 shows the temperature variations within the drying chamber at the top and at the bottom and also outside the drying chamber. The figures also show that the maximum temperature attained was $42.6^{\circ} \mathrm{C}$ and $38.4^{\circ} \mathrm{C}$ and a minimum temperature of $27.5^{\circ} \mathrm{C}$ and $27.1^{\circ} \mathrm{C}$ respectively. From the experimental evaluation tests, results also show that the drying specimens reached an acceptable dryness just within 3 hours and 30 minute with a temperature difference of about $4.2^{\circ} \mathrm{C}$, this could be as a result of the reflector booster.

\section{CONCLUSION}

A hybrid standalone solar clothes drying system has been developed and tested experimentally under both outdoor and indoor controlled tests. The outdoor environment was not favourable for evaluation of the effects of various components; hence, the comparative evaluation experiments were conducted using indoor controlled conditions to enable physical and analytic observation of the developed standalone solar clothes drying system. The system performance result shows moisture removal and temperature difference varied relative to the solar radiation level and drying air mass flow rates. 
The results further confirmed clothes drying could be conducted with a solar radiation level as $10 \mathrm{~W}$ as $200 \mathrm{~W} / \mathrm{m}^{2}$. The experimental results compared favourably with the theoretical results moisture removal (drying rates) at various solar radiation level and air flow rates.

The result shows that copper is the best material for high performance efficiency in regards to solar thermal applications followed by aluminium. But aluminium was used for the construction of the solar clothes drying system because it was cheaper. The main reason for optimization of the solar thermal drying system was to find the best materials for the construction of the hybrid solar drying system with less cost and high efficiency. Copper tube was used for the heat pipes after testing other heat pipes materials. The specimen that was used for the experiments was a white laboratory coat and an Ankara fabric.

The variation in temperature was as a result of the weather condition (it was a wet and raining weather). Even with these conditions, the solar drying system was able to dry a pair of clothes within 3 hours during the outdoor test and about 3 hours and 45 minutes during the indoor test with a relative humidity of $30 \%$.

The economic analysis was carried out to find the net benefit and payback period. The payback period is small compared to the life of the solar dryer system. This clearly establishes that the hybrid solar drying system is economic and environmentally friendly.

\section{ACKNOWLEDGMENT}

I appreciate my supervisors and the staffs of the department of physics university of Ilorin for their support during the research work.

\section{REFERENCES}

[1] Ekechukwu O.V. and Norton B (1999). Review of solar-energy drying systems II: an overview of solar drying technology. Energy Conversion \& Management 40 615-655.

[2] Diamante L. M. and Munro P.A (2004). Mathematical Modeling of thin layer solar drying of sweet potatoes: Solar Energy, Vol, 51 pp 176 - 271.

[3] Ekechukwu O.V. and Norton B (1999). Review of solar-energy drying systems III: low temperature air-heating solar collectors for crop drying applications. Energy Conversion \& Management 40 657-667.

[4] Abhat A. (1983), Low temperature latent heat thermal energy storage: heat storage materials. Solar Energy 30:313-32.

[5] Ahmadul A. and Saiful B. (2004)., Investigation into the effectiveness of heat pump assisted clothes dryer for humid tropics. Energy Conversion and Management 45 1397-1405.

[6] Ahmet S. and Ali K.(2008), Preparation, thermal properties and thermal reliability of capris acid/expanded perlite composite for thermal energy storage. Materials Chemistry and Physics 109 459-464. 